of the fragment with the skulls of a number of medieval women from Glasgow, which also show the abnormality of a supra-occipital bone such as is present in the Lloyd's skull, and has found it in all essentials of the modern type; while Miss Garrod, after a re-examination of the stratigraphical and archæological evidence, has arrived at the conclusion that it is Mousterian, or even earlier.

\section{Ancient Cave-Dwellers in Texas}

From the point of view of the student of the ancient cultures of North America, the investigations which are now being earried out by the Smithsonian Institution of Washington in the south-western United States are at present by far the most interesting in American archæology. It would seem well within the bounds of probability that the Basket-Maker-Pueblo sequence will be amply documented at no very distant date, if researches continue to be prosecuted with the vigour and success of the last few years. The Smithsonian Institution now announces the successful result of an expedition, of which Mr. Frank M. Setzler was in charge, to Texas. This expedition has just returned to Washington after exploring seven caves spread over a wide area in the Big Band and Chisos mountain region of south-eastern Texas. A considerable amount of cultural material was found, which points to the caves having been the permanent habitation of a very primitive race of Indian, unfortunately without any indication of its affinities. It is possible that it may be related to the Basket-Makers of Arizona and New Mexico, who were partially cave-dwellers; but there are differences in culture, especially in the basketry and arrow-shaft techniques. The food of the Texan cave-dwellers appears to have been principally cactus, of which they chewed the pulp and spat out the fibre. This was supplemented by the flesh of bear, deer, rabbits, and birds of all kinds. Their clothing and baskets were woven of cactus fibre. The most remarkable custom, however, was that of burying the body of a small child, never more than two years old, in the exact centre of the caves which were their dwellings, a characteristic they shared with some of the ancient Mayas.

\section{Research Management and Budgeting}

To a symposium on the management of research, appearing in recent issues of Industrial and Engineering Chemistry, W. A. Hamor and G. D. Beal contribute a paper on the control of research expense (April 1932, p. 427). The recognition of the importance of planning and control in management, which has become widespread during the last ten years, has led to the administration of research being placed on $\mathbf{a}$ much more accurate basis. The progress in the control of research expenses made possible by systematic planning and budgeting has been to the joint advantage of management, technology, and science in that due attention can be given, in planning research, to the probability of the solution of a problem at a cost commensurate with its value. All research expense cannot, of course, be reduced to a method of account. ing, but positive savings which can be classified should be accounted as such and duly credited against the improvement in process efficiency, reduction or disposal of wastes, patents, etc., the remaining research expense concerned with the maintenance of quality through control, improved, or novel products being charged off to product and market improvements.

AN accounting system will guard against the numerous uneconomical practices and wastes that can easily creep in and fritter away resources of time or material. Budgetary control is quite possible in spite of being based on estimates because it is not a substitute for management; and when reasonably close estimates have been prepared, the expenditure of the sum to the most advantage will largely depend upon the director. The methods of control adopted, while sufficiently elastic, should enable time and materials to be costed up against the laboratory investigation on which they have been expended, whether improvement of existing processes or products or the discovery of new products or processes, other expenses such as cleaning, light, heat, power, etc., being charged on a pro rata basis. In such budgeting and control, the question of salaries and increases of salary and travelling allowances will be considered from a broad point of view, calculated to encourage the development of scientific enthusiasm and the stimulus of contact with other professional workers at scientific meetings.

\section{Volcanic Steam for Power Generation}

ON July 22, Prince Ginori Conti gave a lecture to the International Union of Power Producers at the hall of the French Institution of Civil Engineers. The possibility of utilising the heat energy in the interior of the earth has frequently been considered by engineers, but in practice it is necessary that the heat be localised near the surface of the earth if this is to be done on a commercial basis. In Tuscany, not far from Florence, Prince Conti has an installation in a volcanic region where low pressure steam issues from cracks in the ground. A system of boring has recently been adopted to obtain the vapour at a higher pressure and increase its volume. The vapour is charged with sulphur, borax, and carbon dioxide. For many years borax has been obtained from the ground round the vent-holes, on which much of the vapour was condensed. Owing to the corrosive nature of the vapour, it was very difficult to design suitable apparatus. At one of the stations the steam generated in the boilers is used to supply suitable low pressure turbines. At another station high pressure steam is employed. Aluminium is used for the conductors in the stations, as copper corroded much too quickly. The total capacity exceeds 12,000 kilowatts, but there are several difficulties still to be overcome. The problem is simpler at Sonoma, in California, where the unwanted gases are easily eliminated from the vapour. The hot vapour is found at depths of between 100 and 200 yards. At present this station supplies $11,000 \mathrm{kw}$. to the surrounding district. According to World Power of July, there is a large quantity of power available in the volcanic regions of Bolivia. 